DOI: $10.19195 / 0524-4544.327 .3$

\author{
MACIEJ BŁAŻEWSKI \\ ORCID: 0000-0003-2812-8199 \\ Uniwersytet Wrocławski \\ maciej.blazewski@uwr.edu.pl
}

\title{
Elektroniczne aspekty w organizacji i przebiegu zgromadzeń
}

\begin{abstract}
Abstrakt: Przepisy ustawy — Prawo o zgromadzeniach określają stosowanie środków komunikacji elektronicznej w związku z organizacją zgromadzenia. Stosowanie tych środków ma miejsce w toku postępowania w sprawie zgromadzenia oraz w związku z przeprowadzeniem tego zgromadzenia. Przepisy prawa zakładają stosowanie podstawowych środków komunikacji, takich jak poczta elektroniczna oraz publiczne strony internetowe, dzięki czemu elektroniczna administracja może być upowszechniona pomimo dużego poziomu wykluczenia cyfrowego w polskim społeczeństwie.
\end{abstract}

Słowa kluczowe: zgromadzenie, organ gminy, środki komunikacji elektronicznej, elektroniczna administracja.

\section{Wstęp}

Rozwój technologii teleinformatycznej ma znaczenie dla większości sfer działania administracji publicznej, w tym także umożliwienia wykonania konstytucyjnej wolności organizowania pokojowych zgromadzeń ${ }^{1}$. W ciągu ostatnich kilkunastu lat przepisy prawa stopniowo i fragmentarycznie wprowadzały możliwość stosowania tej technologii, odnosząc się jedynie do środków komunikacji

1 Zgodnie z art. 57 Konstytucji Rzeczypospolitej Polskiej z dnia 2 kwietnia 1997 r. (Dz.U. z 1997 r. Nr 78, poz. 483 ze zm.), akt ten zapewnia każdemu wolność organizowania pokojowych zgromadzeń i uczestniczenia w nich, a wolność ta może być ograniczona jedynie w drodze ustawy. Jak słusznie wskazuje D. Bogucki, celem elektronicznej administracji jest wykorzystanie technologii teleinformatycznej dla sprawnego wykonywania zadań przez organy administracji publicznej. D. Bogucki, Jaka będzie przyszłość elektronicznej administracji? Część I - trendy, „Czas Informacji” 2011, nr 1, s. 61. Stosowanie technologii ułatwia zatem realizację tej wolności. 
elektronicznej ${ }^{2}$. Aktualny stan prawny uwarunkowujący stosowanie tej technologii jest wynikiem stopniowej adaptacji systemów teleinformatycznych jako narzędzi używanych przy wykonywaniu zadań publicznych przez organy administracji publicznej. Adaptacja ta ma miejsce m.in. poprzez zmiany przepisów prawa, które przewidują nowe mechanizmy stosowania tej technologii ${ }^{3}$.

Celem tego opracowania jest określenie środków komunikacji stosowanych w związku z organizacją i przebiegiem zgromadzeń na podstawie poprzednich regulacji prawnych oraz analiza zakresu zastosowania środków komunikacji elektronicznej zarówno na etapie postępowania w sprawie zgromadzenia, jak i na etapie przeprowadzenia tego zgromadzenia. Kolejnym celem jest wykazanie znaczenia elektronicznych form komunikacji dla zapewnienia szybkości komunikacji oraz skuteczności upowszechnienia informacji dotyczących organizacji zgromadzania.

Opracowanie przedstawia cztery główne elementy problematyki elektronicznych aspektów organizacji i przebiegu zgromadzeń: środki komunikacji w ujęciu historycznoprawnym, środki komunikacji elektronicznej oraz cyfrowe narzędzia komunikacji stosowane $\mathrm{w}$ postępowaniu $\mathrm{w}$ sprawie zgromadzenia $\mathrm{i} \mathrm{w}$ związku z przeprowadzeniem tego zgromadzenia. $Z$ tej przyczyny dokonano analizy poprzednich aktów normatywnych regulujących problematykę zgromadzeń publicznych oraz przedstawiono regulacje ustawy - Prawo o zgromadzeniach z trzech różnych perspektyw.

\section{Środki komunikacji stosowane w związku z organizacją zgromadzenia ujęcie historycznoprawne}

Organizacja zgromadzenia wymaga komunikacji w szczególności pomiędzy jego organizatorem a organem administracji publicznej. Przepisy prawa, wyrażone w każdym akcie normatywnym obowiązującym od odzyskania niepodległości, określały środki komunikacji stosowane przez te podmioty. Zasadniczo była to

2 Ustawa z dnia 24 lipca 2015 r. — Prawo o zgromadzeniach (Dz.U. z 2018 r. poz. 408 ze zm., dalej: u.p.z.). Przepisy prawa wyrażone w tej ustawie odnoszą się jedynie do komunikacji drogą elektroniczną pomiędzy organem administracji publicznej, sądem okręgowym, a organizatorem oraz przewodniczącym zgromadzenia. Zob. K. Mamak, Komentarz. Prawo o zgromadzeniach, Warszawa 2014, s. 86-87, 89.

${ }^{3}$ Ustawa z dnia 5 lipca 1990 r. Prawo o zgromadzeniach (Dz.U. z 2013 r. poz. 397 ze zm.) przewidywała w art. 9 ust. 1 oraz art. 9 ust. 4 stosowanie środków komunikacji elektronicznej przy doręczeniu decyzji o zakazie zgromadzenia oraz decyzji wydanej w wyniku rozpatrzenia odwołania od decyzji o zakazie zgromadzenia. Zakres stosowania systemów teleinformatycznych określonych w tych regulacjach odpowiada jedynie fragmentowi zakresu stosowania takich systemów określonych w aktualnie obowiązującej u.p.z. z 2015 r. 
pisemna forma komunikacji uzupełniona formą ustną. Elektroniczne środki komunikacji zostały dopuszczone dopiero na przełomie lat dziewięćdziesiątych i dwutysięcznych, w związku z wdrażaniem nowych technologii przez administrację publiczną oraz podmioty prywatne.

Przepisy prawa regulujące problematykę zgromadzeń publicznych były w przeszłości wyrażone m.in. w Ustawie z dnia 5 sierpnia 1922 roku w sprawie wolności zgromadzeń przedwyborczych ${ }^{4}$, Ustawie z dnia 11 marca 1932 roku o zgromadzeniach ${ }^{5}$, Ustawie z dnia 29 marca 1962 roku o zgromadzeniach ${ }^{6}$ oraz Ustawie z dnia 5 lipca 1990 roku Prawo o zgromadzeniach ${ }^{7}$. Przepisy wyrażone w tych ustawach rozróżniały rodzaje środków komunikacji w zależności od podmiotu, który je stosował, a którym był organizator zgromadzenia oraz organ.

Środki komunikacji podejmowane przez organizatora zgromadzenia obejmowały z zasady formę pisemną, a wyjątkowo formę ustną. W każdej z ustaw regulujących problematykę zgromadzeń organizator stosował te środki, składając zgłoszenie zgromadzenia ${ }^{8}$; zawiadomienie o zwołaniu zgromadzenia ${ }^{9}$, lub wniosek o wydanie zezwolenia na zwołanie i odbycie zgromadzenia ${ }^{10}$. Jednie zwoływanie zgromadzenia na podstawie Ustawy z dnia 11 marca 1932 roku o zgromadzeniach wymagały od organizatora stosowania formy pisemnej ${ }^{11}$. Pozostałe akty normatywne dopuszczały także formę ustną ${ }^{12}$. Możliwość wnoszenia zawiadomienia o zgromadzeniu drogą elektroniczną została wprowadzona zmianą k.p.a. w 1999 roku, w świetle której podania mogły być wnoszone m.in. pocztą elektroniczną ${ }^{13}$.

Odrębnie regulowany był przebieg podejmowanej przez organ komunikacji, której adresatem był organizator zgromadzenia. Organ podejmował się tej ko-

${ }^{4}$ Ustawa z dnia 5 sierpnia 1922 r. w sprawie wolności zgromadzeń przedwyborczych (Dz.U. $\mathrm{Nr}$ 66, poz. 594, dalej: u.z.p.1922).

${ }^{5}$ Ustawa z dnia 11 marca 1932 r. o zgromadzeniach (Dz.U. Nr 48, poz. 450, dalej: u.z.1932)

6 Ustawa z dnia 29 marca 1962 r. o zgromadzeniach (Dz.U. Nr 20, poz. 89, dalej: u.z.1962).

7 Ustawa z dnia 5 lipca 1990 r. Prawo o zgromadzeniach (Dz.U. Nr 51, poz. 297, dalej: u.z.1990).

8 Art. 3 w zw. z art. 2 u.z.p.1922. Zob. też S. Kwiecień, Wolność zgromadzeń w świetle ustawodawstwa II RP, „Roczniki Nauk Prawnych” 2013, nr 1, s. 73.

9 Art. 6 ust. 1 u.z.1932 oraz art. 7 ust. 1 u.z.1962., jak również art. 6 ust. 1 u.z.1990.

10 Art. 8 ust. 1 w zw. z art. 8 ust. 3 u.z.1962.

11 Zgodnie z art. 6 ust. 1 u.z.1932 organizator powinien wnieść zawiadomienie o zwołaniu zgromadzenia właściwej władzy w formie pisemnej.

$12 \mathrm{~W}$ świetle art. $3 \mathrm{w}$ zw. $\mathrm{z}$ art. 2 u.z.p. 1922 zgłoszenie zgromadzenia przedwyborczego mogło nastąpić drogą pisemną lub ustnie. Zgodnie z art. 7 ust. 1 u.z. 1962 w zw. z art. 63 § 1 Ustawy z dnia 14 czerwca 1960 r. Kodeks postępowania administracyjnego (tekst jedn. Dz.U. z 2017 r. poz. 1257 ze zm., dalej: k.p.a.) oraz art. 6 ust. 1 u.z. 1990 w zw. z art. 63 § 1 k.p.a. zawiadomienie o zwołaniu zgromadzenia, jako rodzaj podania, może zostać wniesione ustnie do protokołu.

13 W świetle treści art. 63 § 1 k.p.a., nadanej mu przez art. 2 pkt 18 Ustawy z dnia 29 grudnia 1998 r. o zmianie niektórych ustaw w związku z wdrożeniem reformy ustrojowej państwa (Dz.U. Nr 162, poz. 1126). 
munikacji albo wydając decyzję sprzeciwiającą się zwołaniu zgromadzenia, co do którego zostało wniesione wcześniej zawiadomienie ${ }^{14}$, albo wydając decyzję odmawiającą lub udzielającą zezwolenia na zwołanie i odbycie zgromadzenia ${ }^{15}$. Środek komunikacji służący wydaniu tej decyzji miał charakter pisemny. Organ administracji publicznej mógł dopiero od 2010 roku wydać decyzję o zakazie zgromadzenia $\mathrm{w}$ formie dokumentu elektronicznego, co zostało zagwarantowane zmianą ustawy kodeksu postępowania administracyjnego ${ }^{16}$, a następnie doprecyzowane w 2012 roku zmianą ustawy — Prawo o zgromadzeniach, w świetle której decyzja ta powinna być doręczona organizatorowi zgromadzenia za pomocą środków komunikacji elektronicznej ${ }^{17}$.

\section{Środki komunikacji elektronicznej stosowane w związku z organizacją i przebiegiem zgromadzenia}

Komunikacja pomiędzy podmiotami publicznymi (organem administracji publicznej, sądem okręgowym) a organizatorem lub przewodniczącym zgromadzenia może aktualnie odbywać się z zastosowaniem środków komunikacji elektronicznej. Środkami tymi są rozwiązania techniczne, w tym urządzenia teleinformatyczne i współpracujące z nimi narzędzia programowe, umożliwiające indywidualne porozumiewanie się na odległość przy wykorzystaniu transmisji danych między systemami teleinformatycznymi ${ }^{18}$.

Środkami komunikacji elektronicznej są m.in. poczta elektroniczna oraz publiczne strony internetowe ${ }^{19}$. Ustawa - Prawo o zgromadzeniach odnosi się

$14 \mathrm{~W}$ świetle art. 9 ust. 1 u.z.1932, a podobnie w przypadku art. 10 ust. 1 u.z.1962, organ, wydając zakaz odbycia zgromadzenia, powinien był podać go na piśmie do wiadomości zgłaszającego. Zgodnie z art. 9 ust. 1 u.z.1990 decyzja o zakazie zgromadzenia publicznego powinna była być doręczona organizatorowi na piśmie.

15 Art. 10 ust. 1 u.z.1962.

16 W świetle treści art. $107 \S 1$ k.p.a., nadanej mu przez art. 2 pkt 8 Ustawy z dnia 12 lutego 2010 r. o zmianie ustawy o informatyzacji działalności podmiotów realizujących zadania publiczne oraz niektórych innych ustaw (Dz.U. Nr 40, poz. 230), decyzja wydana w formie dokumentu elektronicznego powinna być opatrzona bezpiecznym podpisem elektronicznym weryfikowanym za pomocą ważnego kwalifikowanego certyfikatu.

17 Zgodnie z treścią art. 9 ust. 1 oraz ust. 5 u.z.1990 nadaną mu przez art. 1 pkt 6 Ustawy z dnia 14 września 2012 r. o zmianie ustawy — Prawo o zgromadzeniach (Dz.U. z 2012 r. poz. 1115).

18 Art. 9 ust. 1 u.p.z. w zw. z art. 2 pkt 5 Ustawy z dnia 18 lipca 2002 r. o świadczeniu usług drogą elektroniczną (tekst jedn. Dz.U. z 2016 r. poz. 1030 ze zm.).

19 Zdaniem S. Gajewskiego, środkami komunikacji elektronicznej stosowanymi w związku ze złożeniem zawiadomienia o zamiarze zorganizowania zgromadzenia są także: wiadomości SMS oraz MMS, komunikatory internetowe oraz aplikacje na urządzenia mobilne. Zob. S. Gajewski, Ko- 
do środków komunikacji służących komunikacji wewnętrznej (G2G - Government to Government) oraz zewnętrznej (G2C - Government to Citizen), czyli komunikacji organu administracji publicznej lub sądu okręgowego z podmiotem zewnętrznym wobec administracji, takim jak organizator lub przewodniczący zgromadzania $^{20}$. Przepisy ustawy nie odnoszą się do sposobu komunikacji pomiędzy tymi podmiotami zewnętrznymi.

Komunikacja drogą elektroniczną odbywa się z wykorzystaniem prywatnej poczty elektronicznej organizatora oraz przewodniczącego zgromadzania, jak również publicznej poczty elektronicznej organu gminy, którym jest wójt, burmistrz lub prezydent miasta ${ }^{21}$, gminne (miejskie) centrum zarządzania kryzysowego lub wojewódzkie centrum zarządzania kryzysowego ${ }^{22}$. Adres prywatnej poczty elektronicznej powinien zostać podany w zawiadomieniu o zamiarze zorganizowania zgromadzenia ${ }^{23}$, a adres publicznej poczty elektronicznej powinien być zamieszczony na stronie podmiotowej właściwego organu w Biuletynie Informacji Publicznej ${ }^{24}$. Poczta elektroniczna służy do bezpośredniej komunikacji pomiędzy

mentarz do art. 9, [w:] S. Gajewski, A. Jakubowski, Prawo o zgromadzeniach, Warszawa 2017, s. 71. Głównym środkiem komunikacji elektronicznej związanym z przekazaniem tego zawiadomienia wydaje się jednak poczta elektroniczna, na co wskazuje m.in. wykładania systemowa art. 9 ust. 5 w zw. z art. 9 ust. 1 u.p.z., zgodnie z którą organ gminy udostępnia adres poczty elektronicznej, na który można wysłać zawiadomienie.

20 Te dwa kierunki komunikacji są jednymi z wielu innych kierunków komunikacji. Ustawa - Prawo o zgromadzeniach ogranicza się do kierunku G2G oraz G2C, co jest wystarczające do skutecznych czynności związanych z organizacją zgromadzeń. Problematykę kierunków komunikacji elektronicznej poruszają m.in. E. Ziemba, T. Papaj, J. Będkowski, Egzemplifikacja e-government $w$ Polsce - analiza porównawcza SEKAP i ePUAP, „Roczniki Kolegium Analiz Ekonomicznych" 2013, nr 29, s. 430; K. Batko, G. Billewicz, E-ustugi w biznesie i administracji publicznej, „Studia Ekonomiczne. Zeszyty Naukowe Uniwersytetu Ekonomicznego w Katowicach” 2013, nr 136, s. 50.

21 Pojęcie stosowane w ustawie - Prawo o zgromadzeniach ,organ gminy” oznacza organ wykonawczy gminy, obejmujący zgodnie z art. 26 ust. $1 \mathrm{w}$ zw. z art. 11a ust. 1 pkt 2 Ustawy z dnia 8 marca 1990 r. o samorządzie gminnym (tekst jedn. Dz.U. z 2016 r. poz. 446 ze zm.) wójta, burmistrza oraz prezydenta miasta. Zob. S. Gajewski, Komentarz do art. 7, [w:] S. Gajewski, A. Jakubowski, op. cit.

22 Na zastosowanie poczty elektronicznej w komunikacji elektronicznej pomiędzy organem administracji publicznej a podmiotem zewnętrznym względem tej administracji (organizatorem oraz przewodniczącym zgromadzenia) wskazuje treść przepisów ustawy - Prawo o zgromadzeniach wyrażających obowiązek podania adresu poczty elektronicznej (art. 9 ust. 5 u.p.z.; art. 10 ust. 1 pkt 1 u.p.z.; art. 22 ust. 1 pkt 1 u.p.z.; art. 22 ust. 4 w zw. z art. 22 ust. 1 u.p.z.).

$23 \mathrm{Na}$ zastosowanie do komunikacji elektronicznej prywatnej poczty elektronicznej przewodniczącego oraz organizatora zgromadzenia wskazują regulacje wymagające podania w zawiadomieniu o zamiarze zorganizowania zgromadzenia tychże adresów (art. 10 ust. 1 pkt 1-2 u.p.z.; art. 22 ust. 1 pkt 1 u.p.z.).

24 Organ gminy, gminne (miejskie) centrum zarządzania kryzysowego oraz wojewódzkie centrum zarządzania kryzysowego mają obowiązek stosowania publicznej poczty elektronicznej, na co wskazuje obowiązek organu gminy oraz wojewody upublicznienia na swojej stronie podmio- 
organem administracji publicznej, a organizatorem lub przewodniczącym zgromadzenia.

Drugim rodzajem środków komunikacji elektronicznej są publiczne strony internetowe prowadzone w powiązaniu z Biuletynem Informacji Publicznej ${ }^{25}$. Na tych stronach publikowane są informacje związane $\mathrm{z}$ organizacją zgromadzenia publicznego, w tym o adresach poczty elektronicznej organów administracji publicznej $^{26}$, organizowanym zgromadzeniu ${ }^{27}$ oraz decyzji zakazującej zgromadzenia $^{28}$. Publikacja ma na celu upowszechnienie danych o postępowaniu w sprawie zgromadzenia lub organizowaniu tego zgromadzenia. Powszechne przekazywanie tych informacji może także nastąpić równolegle względem bezpośredniej komunikacji za pośrednictwem poczty elektronicznej ${ }^{29}$. Wzajemne uzupełnienie środków komunikacji elektronicznej ma na celu szybkie przekazanie tych danych do adresata, jakim jest m.in. organizator oraz przewodniczący zgromadzenia.

Stosowanie środków komunikacji elektronicznej jest z zasady obligatoryjne dla organów administracji publicznej oraz sądu okręgowego, a fakultatywne dla podmiotów zewnętrznych wobec administracji publicznej, w tym dla organizatora zgromadzenia. Organ oraz sąd powinien komunikować się bezpośrednio za pomocą poczty elektronicznej tak w kierunku wewnętrznym (G2G), jak i w kierunku zewnętrznym (G2C), gdy organizator zgromadzenia zamierza stosować środki komunikacji elektronicznej w postępowaniu w sprawie o zgromadzeniach. Organizator zgromadzania z zasady fakultatywnie stosuje ten rodzaj środka komunikacji w kierunku zewnętrznym albo wybiera inny sposób porozumiewania się z organem ${ }^{30}$. Takie rozdzielenie obowiązku i prawa stosowania środków komunikacji elektronicznej pomiędzy organ, sąd okręgowy oraz organizatora zgromadzenia jest uwarunkowane dwoma założeniami. Po pierwsze, organy administracji publicznej powinny w swojej działalności upowszechniać stosowanie narzędzi elektronicznej administracji. Organy powinny posiadać w tym celu niezbędną infrastrukturę, powinny również być obsługiwane przez pracowników

towej w Biuletynie Informacji Publicznej adresu poczty elektronicznej (art. 9 ust. 5 u.p.z., art. 22 ust. $4 \mathrm{w}$ zw. $\mathrm{z}$ art. 22 ust. 1 u.p.z.).

25 Zgodnie z art. 8 ust. 1 Ustawy z dnia 6 września 2001 r. o dostępie do informacji publicznej (tekst jedn. Dz.U. z 2016 r. poz. 1764) Biuletyn Informacji Publicznej jest urzędowym publikatorem teleinformatycznym, prowadzonym w celu powszechnego udostępniania informacji publicznej, $\mathrm{w}$ postaci ujednoliconego systemu stron w sieci teleinformatycznej.

26 Art. 9 ust. 5 u.p.z., art. 22 ust. 4 w zw. z art. 22 ust. 1 u.p.z.

27 W myśl art. 7 ust. 3 u.p.z. organ gminy umieszcza na swojej stronie podmiotowej w Biuletynie Informacji Publicznej dane o miejscu oraz terminie zgromadzenia.

28 Zgodnie z art. 15 ust. 1 u.p.z. organ gminy publikuje na swojej stronie podmiotowej w Biuletynie Informacji Publicznej informacje o wydaniu decyzji o zakazie zgromadzenia.

${ }^{29}$ W świetle art. 15 ust. 1 u.p.z. organ gminy przekazuje decyzję o zakazie zgromadzenia organizatorowi tego zgromadzania za pomocą środków komunikacji elektronicznej.

30 Organizator zgromadzenia może wnieść zawiadomienie o zamiarze zorganizowania zgromadzenia za pomocą środków komunikacji elektronicznej. Organizator może także przekazać to zawiadomienie pisemnie, ustnie do protokołu lub faksem (art. 9 ust. 1 u.p.z.). 
posiadających odpowiednie kwalifikacje techniczne ${ }^{31}$. Drugie założenie dotyczy znacznego stopnia wykluczenia cyfrowego $\mathrm{w}$ polskim społeczeństwie ${ }^{32}$. Przepisy prawa o zgromadzeniach przeciwdziałają wykluczeniu poprzez umożliwianie stosowania najpopularniejszych środków komunikacji elektronicznej, jakimi są poczta elektroniczna oraz strony internetowe, do których dostęp jest otwarty ${ }^{33}$. Ze względu na duży stopień wykluczenia cyfrowego prawodawca uznał, że komunikacja w kierunku zewnętrznym, czyli pomiędzy organem a organizatorem zgromadzenia, jest fakultatywnie prowadzona w formie elektronicznej.

\section{Elektroniczne aspekty postępowań w sprawie zgromadzeń}

Środki komunikacji elektronicznej mogą być stosowane w prawie każdym etapie postępowania w sprawie zgromadzenia, jak również po jego zakończeniu. Elektroniczna komunikacja odbywa się pomiędzy organem administracji publicznej, organizatorem zgromadzenia, oraz sądem okręgowym, do którego wniesiono decyzję o zakazie zgromadzenia.

Postępowanie w sprawie zgromadzenia jest wszczynane na podstawie zawiadomienia o zamiarze jego przeprowadzenia. Organizator może zastosować środek komunikacji elektronicznej jako formę wniesienia tego zawiadomienia do organu gminy, a w przypadku postępowania uproszczonego do gminnego (miejskiego) centrum zarządzania kryzysowego lub wojewódzkiego centrum zarządzania kryzysowego $^{34}$. Organizator do zawiadomienia może dołączyć elektroniczną kopię

31 Nauka prawa wskazuje jednakże, że barierą dla rozwoju elektronicznej administracji jest niski poziom cyfryzacji wśród pracowników administracji publicznej. Zob. D. Bogucki, Jaka będzie przyszłość elektronicznej administracji? Część II..., s. 84. Na problemy związane z wdrożeniem elektronicznej administracji wskazuje także M. Stachowicz i S. Mamrot, Standaryzacja jako czynnik optymalizacji ustug świadczonych przez administrację publiczna, „Samorząd Terytorialny” 2015, nr 5, s. 67.

32 Nauka prawa wskazuje, że wykluczenie cyfrowe ma duży wpływ na efektywność stosowania przepisów dotyczących elektronicznej administracji. Zob. K. Schmidt, Zmiany w ustawie o informatyzacji a instrukcje kancelaryjne, „Czas Informacji” 2010, nr 1, s. 30; D. Bogucki, Jaka będzie przyszłość elektronicznej administracji? Część I..., s. 61.

33 Zapewnienie możliwości stosowania powszechnie dostępnych środków komunikacji elektronicznej może pozwolić na zwiększenie popularności komunikacji elektronicznej w kierunku G2C. Jak słusznie zauważa M. Tabor, łatwe do stosowania narzędzia tego rodzaju komunikacji będą podstawą dla zwiększenia motywacji obywatela do ich wykorzystania. Zob. M. Tabor, Dokument elektroniczny w administracji publicznej - czas na zmiany, „Czas Informacji” 2010, nr 2, s. 6.

34 Zgodnie z art. 9 ust. 1 w zw. z art. 9 ust. 5 u.p.z. organizator zgromadzenia może zawiadomić organ gminy o zamiarze zorganizowania zgromadzenia za pomocą poczty elektronicznej tego organu, której adres został udostępniony na stronie podmiotowej gminy w Biuletynie Informacji Publicznej. W świetle art. 22 ust. 3 w zw. z art. 22 ust. 1 oraz art. 21 u.p.z. zawiadomienie o zamia- 
zgody na przyjęcie obowiązków przewodniczącego tego zgromadzenia ${ }^{35}$. Kopia ta może mieć formę skanu lub cyfrowego zdjęcia zgody sporządzonej wcześniej $\mathrm{w}$ formie pisemnej ${ }^{36}$.

Czynności przeprowadzone w toku tego postępowania mogą być dokonane w formie elektronicznej. Organ gminy wzywa za pomocą środków komunikacji elektronicznej do zmiany miejsca lub czasu planowanego zgromadzenia, które mogłoby kolidować z wcześniej zgłoszonym zgromadzeniem ${ }^{37}$. Organ gminy powinien także w formie elektronicznej wezwać organizatorów zgromadzeń do uczestnictwa w rozprawie administracyjnej, która ma na celu usprawnienie uzgodnienia zmiany miejsca lub czasu zgromadzenia ${ }^{38}$.

Organ gminy, wydając decyzję o zakazie zgromadzenia, ma obowiązek niezwłocznego udostępnienia jej na stronie podmiotowej tego organu w Biuletynie Informacji Publicznej, jak również przekazania jej organizatorowi z zastosowaniem środków komunikacji elektronicznej ${ }^{39}$. Skutkiem publikacji na stronie podmiotowej jest domniemanie jej doręczenia stronie postępowania ${ }^{40}$.

Po zakończeniu postępowania, komunikacja elektroniczna ma miejsce pomiędzy sądem okręgowym a organem gminy ${ }^{41}$. Sąd okręgowy ma obowiązek niezwłocznie zawiadomić organ gminy o wniesieniu odwołania od decyzji o zakazie zgromadzenia poprzez udostępnienie informacji o jego wniesieniu na stronie podmiotowej tego sądu w Biuletynie Informacji Publicznej. Sąd okręgowy jednocześnie przekazuje $\mathrm{w}$ drodze elektronicznej informacje o terminie rozprawy organizatorowi zgromadzenia oraz organowi gminy ${ }^{42}$.

rze zorganizowania zgromadzania, które nie będzie powodować utrudnień w ruchu drogowym, a w szczególności powodować zmiany w jego organizacji, organizator może przesłać na pocztę elektroniczną organu lub centrum zarządzania kryzysowego, której adres jest podany odpowiednio na stronie podmiotowej gminy w Biuletynie Informacji Publicznej albo stronie podmiotowej wojewody w Biuletynie Informacji Publicznej. Zob. S. Gajewski, Komentarz do art. 22, [w:] S. Gajewski, A. Jakubowski, op. cit., s. 167.

35 Art. 10 ust. 3 w zw. z art. 10 ust. 2 pkt 1 u.p.z.

36 S. Gajewski, Komentarz do art. 10, [w:] S. Gajewski, A. Jakubowski, op. cit., s. 78.

37 Art. 12 ust. 2 w zw. z art. 12 ust. 1 u.p.z.

38 Art. 13 ust. 2 w zw. z art. 13 ust. 1 u.p.z.

39 Art. 15 ust. 1 u.p.z. Zdaniem A. Jakubowskiego, opublikowanie decyzji na stronie podmiotowej w Biuletynie Informacji Publicznej oznacza np. podanie linku strony internetowej, na której została umieszczona pełna treść tej decyzji. A. Jakubowski, Komentarz do art. 15, [w:] S. Gajewski, A. Jakubowski, op. cit., s. 122.

40 Art. 15 ust. 2 w zw. $z$ art. 15 ust. 1 u.p.z.

41 Zdaniem A. Jakubowskiego, odwołanie od decyzji o zakazie zgromadzenia powinno zostać wniesione drogą pisemną, ponieważ przepisy ustawy — Prawo o zgromadzeniach nie przewidują w sposób wyraźny stosowania środków komunikacji elektronicznej. A. Jakubowski, Komentarz do art. 16, [w:] S. Gajewski, A. Jakubowski, op. cit., s. 125. Komunikacja elektroniczna odbywa się jednakże w kierunku wewnętrznym pomiędzy organem gminy a sądem okręgowym.

42 Art. 16 ust. 2 u.p.z. A. Jakubowski podkreśla, że sąd okręgowy powinien udostępnić także na swojej stronie podmiotowej w Biuletynie Informacji Publicznej link do pliku zawierającego zanonimizowaną treść wyroku zapadłego na podstawie wniesionego odwołania od decyzji o zakazie zgromadzenia.

Prawo 327, 2019

(C) for this edition by CNS 
Celem stosowania środków komunikacji elektronicznej w związku z postępowaniem w sprawie zgromadzenia jest zapewnienie szybkości przekazywania informacji. Komunikacja elektroniczna może odbywać się w czasie rzeczywistym, co ma istotne znaczenie dla czynności podejmowanych w toku tego postępowania, ze względu na krótkie terminy określone w ustawie — Prawo o zgromadzeniach ${ }^{43}$.

\section{Elektroniczne aspekty przeprowadzenia zgromadzenia}

Środki komunikacji elektronicznej umożliwiają także szybkie upowszechnienie informacji o przeprowadzonym zgromadzeniu oraz ułatwiają komunikację pomiędzy organem administracji publicznej a przewodniczącym zgromadzenia.

Organ gminy oraz wojewoda mają obowiązek publikacji informacji o zgromadzaniu w formie elektronicznej ${ }^{44}$. Publikacja powinna mieć miejsce na stronie podmiotowej Biuletynu Informacji Publicznej tych organów. Elektroniczna publikacja tych informacji jest skierowana do dwóch rodzajów podmiotów: uczestników zgromadzenia oraz osób trzecich. Uczestnicy mogą uzyskać dzięki tej publikacji informacje o organizatorze i przewodniczącym zgromadzenia, jak również o miejscu i czasie jego przeprowadzenia ${ }^{45}$. Dane te umożliwią uczestnikom udział

43 Krótkie terminy związane z zapewnieniem informacji o organizacji zgromadzenia dotyczą m.in. czasu złożenia zawiadomienia o zamiarze zorganizowania zgromadzenia (art. 7 ust. 1 u.p.z.; art. 22 ust. 1 u.p.z.); wniosku o wyrażenie zgody na cykliczne organizowanie zgromadzeń (art. 26a ust. 3 u.p.z.); wezwania organizatorów zgromadzeń do uczestnictwa w rozprawie administracyjnej (art. 13 ust. 2 zd. 1 u.p.z.); wydania decyzji o zakazie zgromadzenia (art. 14 u.p.z.); odwołania od decyzji o zakazie zgromadzenia (art. 16 ust. 1 u.p.z.); odwołania od decyzji o rozwiązaniu zgromadzenia (art. 20 ust. 4 u.p.z.; art. 25 ust. 4 u.p.z.).

44 Zgodnie z art. 7 ust. 3 u.p.z. organ gminy udostępnia na swojej stronie podmiotowej w Biuletynie Informacji Publicznej informacje o zgromadzeniu po otrzymaniu zawiadomienia o zamiarze jego zorganizowania. W świetle art. 22 ust. 5 u.p.z. organ gminy i wojewoda udostępniają na swojej stronie podmiotowej w Biuletynie Informacji Publicznej informacje o zgromadzeniu, które zostało zorganizowane w postępowaniu uproszczonym. W myśl art. 26b ust. 2 u.p.z. wojewoda udostępnia na swojej stronie podmiotowej w Biuletynie Informacji Publicznej informacje o zgromadzeniu organizowanym cyklicznie. Jak słusznie zauważa S. Gajewski, obowiązek publikacji tych informacji na stronie internetowej biegnie od chwili złożenia zawiadomienia o zamiarze zorganizowania zgromadzania, które nie zawiera braków. S. Gajewski, Komentarz do art. 7..., [w:] S. Gajewski, A. Jakubowski, op. cit., s. 65.

45 Zgodnie z art. 7 ust. 3 u.p.z. organ gminy udostępnia na swojej stronie podmiotowej w Biuletynie Informacji Publicznej informacje o miejscu i terminie organizowanego zgromadzenia. W świetle art. 22 ust. 5 u.p.z. organ gminy i wojewoda udostępniają na swojej stronie podmiotowej w Biuletynie Informacji Publicznej informacje o miejscu i terminie zgromadzenia, które zostało zorganizowane w postępowaniu uproszczonym. W myśl art. 26b ust. 2 u.p.z. wojewoda udostępnia na swojej stronie podmiotowej w Biuletynie Informacji Publicznej informacje o miejscu i terminie zgromadzeń organizowanych cyklicznie.

Prawo 327, 2019

(C) for this edition by CNS 
w zgromadzeniu ${ }^{46}$. Osoby trzecie także mogą uzyskać te informacje. Dla osób trzecich, którymi mogą być podmioty planujące przeprowadzenie innego zgromadzenia, dane o czasie i miejscu organizacji zgromadzenia są istotne ze względu na regulacje uniemożliwiające ich kolizję.

Kolejną funkcją środków komunikacji elektronicznej jest zapewnienie łączności pomiędzy organem gminy a przewodniczącym zgromadzenia. Prawo o zgromadzeniach nakłada bowiem na przewodniczącego zgromadzenia obowiązek pozostawania w kontakcie z przedstawicielem organu gminy ${ }^{47}$. Kontakt ten ma na celu umożliwienie wykonania obowiązku zapewnienia przebiegu zgromadzenia zgodnie z przepisami prawa oraz zapobiegnięcie powstaniu szkód z winy jego uczestników ${ }^{48}$. Organ gminy może kontaktować się z przewodniczącym zgromadzenia za pośrednictwem poczty elektronicznej, której adres został wcześniej podany w zawiadomieniu o zamiarze zorganizowania zgromadzenia ${ }^{49}$.

Przepisy regulujące przeprowadzenie zgromadzenia mają na celu zapewnienie powszechnego dostępu do informacji dotyczących tego zgromadzenia, jak również ułatwienie współpracy pomiędzy organem gminy a przewodniczącym tego zgromadzenia.

\section{Zakończenie}

Stosowanie elektronicznych środków komunikacji było wprowadzone stopniowo, a aktualne przepisy ustawy - Prawo o zgromadzeniach nadal określają możliwość stosowania jedynie podstawowych środków komunikacji elektronicznej, takich jak poczta elektroniczna oraz strona internetowa. Ustawa ta odnosi się do każdego aspektu komunikacji związanej z organizacją i przebiegiem zgromadzenia. Przepisy, nakładając obowiązek stosowania środków komunikacji elektronicznej przez organ administracji publicznej oraz sąd okręgowy, jak również prawo ich stosowania przez organizatora i przewodniczącego zgromadzenia, uwzględniają uwarunkowania technologiczne oraz społeczne związane ze stosowaniem podstawowych środków komunikacji elektronicznej, do których każdy ma otwarty dostęp, jak również wysoki poziom wykluczenia cyfrowego w polskim społeczeństwie.

46 Zdaniem S. Gajewskiego publikacja informacji o organizacji zgromadzania na stronie internetowej może przyczynić się także do zwiększenia frekwencji na tym zgromadzaniu. Zob. S. Gajewski, Komentarz do art. 7..., [w:] S. Gajewski, A. Jakubowski, op. cit., s. 65.

47 Art. 19 ust. 2 u.p.z.

48 Art. 19 ust. 1 zd. 1 w zw. z art. 19 ust. 2 u.p.z.

49 Zgodnie z art. 10 ust. 1 pkt 2 u.p.z. organizator powinien podać w zawiadomieniu o zamiarze zorganizowania zgromadzeniu m.in. adres poczty elektronicznej przewodniczącego tego zgromadzenia, w celu umożliwienia kontaktu z nim. 


\title{
Bibliografia
}

Batko K., Billewicz G., E-ustugi w biznesie i administracji publicznej, „Studia Ekonomiczne. Zeszyty Naukowe Uniwersytetu Ekonomicznego w Katowicach” 2013, nr 136, s. 50.

Bogucki D., Jaka będzie przyszłość elektronicznej administracji? Część I - trendy, „Czas Informacji” 2011, nr 1.

Bogucki D., Jaka będzie przyszłość elektronicznej administracji? Część II - perspektywy, „Czas Informacji” 2011, nr 2.

Gajewski S., Jakubowski A., Prawo o zgromadzeniach, Warszawa 2017

Kwiecień S., Wolność zgromadzeń w świetle ustawodawstwa II RP, „Roczniki Nauk Prawnych” 2013, nr 1.

Mamak K., Komentarz. Prawo o zgromadzeniach, Warszawa 2014.

Schmidt K., Zmiany w ustawie o informatyzacji a instrukcje kancelaryjne, „Czas Informacji” 2010, nr 1.

Stachowicz M., Mamrot S., Standaryzacja jako czynnik optymalizacji ustug świadczonych przez administracje publiczna, „Samorząd Terytorialny” 2015, nr 5.

Tabor M., Dokument elektroniczny w administracji publicznej - czas na zmiany, „Czas Informacji” 2018, nr 2 .

Ziemba E., Papaj T., Będkowski J., Egzemplifikacja e-government w Polsce - analiza porównawcza SEKAP i ePUAP, „Roczniki Kolegium Analiz Ekonomicznych” 2013, nr 29.

\section{Electronic aspects of organization and conduct of assemblies}

\author{
Summary
}

The provisions of the Law on Assemblies Act regulate the use of electronic means of communication during the organization of a public assembly. The application of these means of communication takes place during the proceedings for the organization of an assembly and in connection with its conduct. The provisions allow the use of basic means of communication, such as e-mail and public websites so that electronic administration could be disseminated despite the high level of digital exclusion in society in Poland.

Keywords: public assembly, municipal authority, electronic means of communication. 